\title{
Relationship between Asian Emerging Stock Markets and Economic Fundamentals: A Cointegration and Block Exogeneity Wald Approach
}

\author{
Submitted 17/03/20, 1st revision 13/04/20, 2nd revision 21/05/20, accepted 30/07/20
}

\begin{abstract}
:
Velip Suraj Pavto ${ }^{1}$, Guntur Anjana Raju²

Purpose: The stock market performance is the function of the current and future level of economic activity. In view of this, the study examines the short-run and long-run association between Asian emerging stock markets and their economic fundamentals.

Design/Methodology/Approach: The sample size of the study consists of nine Asian emerging stock markets namely China, India, Indonesia, South Korea, Malaysia, Pakistan, Philippines, Taiwan and Thailand and their macroeconomic determinants such as Consumer Price Index (CPI), Export, Import, Exchange Rate (Forex), Industrial Production Index (IP), Broad Money Supply (MS) and Short-term Interest Rate (IR). Each stock market is investigated using the Johansen Cointegration test and Vector Error Correction Causality/Block Exogeneity Wald test. The study used monthly data observations from January 2000 to August 2019.

Findings: The cointegration result provided incremental information on the long-run relationship between stock prices and macroeconomic variables. However, the causality between stock prices and macroeconomic variables are considerably limited in the shortrun.

Practical Implications: The insight on the linkages between stock prices and economic fundamentals will provide the opportunity for short-run and long-run investment decisions in the Asian emerging stock markets.

Originality/Value: The result of this study would amplify the understanding on the extent of integration between Asian emerging stock markets and macroeconomic variables. This would be a significant incentive to figure out a risk-reward opportunity from these markets.
\end{abstract}

Keywords: Asian emerging stock markets, macroeconomic variables, cointegration, causality.

JEL Code: E44, F36, G15.

Paper Type: Research article.

\footnotetext{
${ }^{1}$ Ph.D. Research Scholar and Assistant Professor, Goa Business School, Goa University, Goa, India, 403 206, e-mail: suraj@unigoa.ac.in

${ }^{2}$ Professor and Program Director of Ph.D. (Commerce), Goa Business School, Goa University, Goa, India, 403 206, e-mail: anjana@unigoa.ac.in
} 


\section{Introduction}

Since the last two decades a large number of global players extensively attracting towards Asian emerging stock markets as an investment venue. The tremendous experience of economic and financial growth led this market as one of the first choice of investment town for investors. According to MSCI annual index performance report (2019), the average growth rate of returns from 2004 to 2019 for MSCI aggregate emerging market index is $12.97 \%$ which is higher than that of MSCI developed and frontier market indexes (9.02\% and $9.62 \%$, respectively). Individually, the average share of nine Asian emerging markets i.e., China, India, Indonesia, Korea, Malaysia, Pakistan, Philippines, Taiwan and Thailand in the aggregate MSCI emerging market index performance grew up to $15.91 \%, 17.52 \%$, $20.80 \%, 13.08 \%, 9.57 \%, 13.02 \%, 16.72 \%, 10.89 \%$ and $15.62 \%$ respectively. Therefore, except Malaysia and Taiwan, all other indexes' performance is above MSCI emerging market average performance. The significant growth in Asian emerging markets resulted due to various financial reforms, liberalization of markets and other initiatives undertaken by the respective country.

However, due to globalization, widespread market liberalization, bilateral trade activities and opening economy for foreign activities enhanced the integration between cross-border equity markets. Further, this has created an important discussion theme among the researchers since it is directly related to investment and portfolio diversification. Over a period of years particularly from the early $21^{\text {st }}$ century, overwhelming attention has received to examine Asian emerging stock market integration and portfolio diversification opportunities. Studies such as (Dunis and Shannon, 2005), (Batareddy et. al., 2012) and (Loong and Har, 2017), their findings suggested diversification opportunity in the Asian emerging markets tending to reduce due to strong inter-dependency between the markets. So far, researchers in financial literature drew a lot of attention towards integration between the Asian emerging stock market.

Conversely, the question left to address that, which macroeconomic variables drive the movement of Asian emerging markets stock prices? According to the Efficient Market Hypothesis propounded by (Fama, 1970), stock prices change rapidly with the flow of new information and movement in macroeconomic forces. Grossman and Shiller (1980) pointed out that the present value of expected dividend from stocks and the firm's ability to generate cash flows related to current and future levels of economic activity. Therefore, portfolio investors need to understand the association between stock prices and economic parameters in order to figure out risk-rewards opportunity through diversification in Asian emerging stock markets. In fact, it has justified that the state of macroeconomic variables across a globe reflects the financial market performance and investment opportunities. Therefore, this study addresses the integration of Asian emerging stock markets with a set of macroeconomic variables. 


\section{Literature Review}

Considering the theoretical backdrop, many studies modeled the relationship between stock prices and macroeconomic variables. Pal and Mittal (2011) established a long-run relationship between Indian stock indices and macroeconomic variables such as interest rate, inflation rate, exchange rate and GDP. The result of the sstudy by Giri and Joshi (2017) showed that economic growth, inflation and exchange rate have a positive impact on Indian stock prices whereas crude oil prices share a negative impact. A study by Sohail and Hussain (2009) and Umer (2016) also found cointegration between the Pakistan stock market and selected macro variables. The studies consistently pointed out the positive effect of money supply on the stock returns of Pakistan in the long-run. Ibrahim (2003) and Brahmasrene and Jiranyakul (2007) from the Malaysian and Thailand perspective also noted the significant positive influence of money supply on equity prices.

Valukonis (2013), findings claimed that China stock price movement is more related to inflation and GDP. From the Indonesian case Surbakti et al. (2016) argued that only one macroeconomic variable such as exchange rate exerts a positive impact on stock prices while gold prices, interest rate and inflation shows the insignificant effect on stock index returns. Kwon and Shin (1999) also observed direct long-run and equilibrium relationships between Korean stock prices and variables such as foreign exchange rate, trade balance, production level and money supply. Some other handful of studies also documented the relationship between emerging stock markets and macroeconomic determinants. Maysami and Hui (2001) and Hosseini et al. (2011) concluded that India, China, Malaysia and Thailand stock markets are associated with the set of macroeconomic variables in the short and long-run.

However Lee (1997) argued that Hong Kong, Singapore, South Korea and Taiwan are not efficient with respect to macroeconomic policies such as money supply and budget deficit. The result of interaction between stock prices of ASEAN-5 and macroeconomic variables provides a contribution for decent Government economic and financial policies (Wongbangpo and Sharma, 2002). The twenty selected markets are showing more variation due to local factors such as money supply, goods prices, real activity, and exchange rate than domestic factors (Bilson et al., 2001). Pretorius (2002) from their finding stated that a substantial proportion of interdependency between selected emerging stock markets is explained by economic activity. In the study of Asian economic integration and stock market co-movement Johnson and Soenen (2002) suggested higher import, inflation rate, real interest rate and GDP growth share a negative effect on the stock movement of Asia. Thalassinos and Thalassinos (2006) and Thalassinos et al. (2015) have examined the effect of macroeconomic variables on stocks and credit swaps.

Nevertheless, Eiling and Gerard (2015) mentioned the official market liberalization, continuous initiatives of equity market openness, equity market development and even trade openness plays a major role in driving cross-country correlation in most 
of the selected emerging stock markets. In light of the above financial literature, this study examines the short-run and long-run linkages of Asian emerging stock prices with the group of its economic parameters.

\section{Data and Methodology}

According to MSCI 2019 annual market classification, nine Asian markets are falling under the MSCI emerging market index. The study incorporates these nine Asian emerging stock markets including China (SHCOM), India (Nifty Fifty), Indonesia (JKSE), Korea (KOSPI), Malaysia (KLCI), Pakistan (KSE-100), Philippines (PSEI), Taiwan (TWI) and Thailand (SET) as a sample size. Similarly, the set of macroeconomic variables for each country consist of Consumer Price Index (CPI), Export, Import, Exchange Rate (Forex), Industrial Production Index (IP), Broad Money Supply (MS) and Short-term Interest Rate (IR) used as a proxy of economic activity. The monthly frequency data for each country's equity index and macroeconomic variables covering data period from January 2000 to August 2019 obtained from Bloomberg and International Financial Statistics (IFS).

The Johansen Cointegration and the Causality/Block Exogeneity Wald test based on the Vector Error Correction Model (VECM) used to identify the short-run and longrun relationship between stock prices and underlying macroeconomic variables. However, the first step involved in the analysis is checking for the order of integration or a test for stationarity of the variables. The Augmented Dickey-Fuller (ADF) test of unit root introduced by Dickey and Fuller (1979), employed to infer stationarity property for each of the variables. To test for stationarity, the following is the ADF equation:

$\Delta \mathrm{Y}_{\mathrm{t}}=\alpha+\beta \mathrm{T}+\rho \mathrm{Y}_{\mathrm{t}-1}+\sum_{\mathrm{i}=1}^{\mathrm{k}} \gamma_{\mathrm{i}} \Delta \mathrm{Y}_{\mathrm{t}-\mathrm{i}}+\varepsilon_{\mathrm{t}}$

Where $Y_{t}$ is the variable at time $t, \Delta$ is the differencing operator, $\alpha$ is constant, $\beta \mathrm{T}$ is coefficient on a time trend, $\rho$ is the lag order of the Autoregression (AR) process and $\mathcal{E}_{\mathrm{t}}$ is an error term.

The null hypothesis $Y_{t}$ have unit root is rejected against alternative hypothesis $Y_{t}$ does not have unit root when $\mathrm{ADF}$ test statistics is less than the critical value. If the series has a unit root at the level $\mathrm{I}(0)$ then the ADF test will be performed by first differencing the series. And if variables found stationary after differencing then it is said to be integrated of order one I(1). If the set of variables reveals integrated order, then there are possibilities of cointegration or long-run association between the variables. Beginning with the procedure of Johansen Cointegration test, the equation of Multivariate VAR model of order $\mathrm{p}$ is as follows:

$y_{t}=A_{1} y_{t-1}+\ldots+A_{p} y_{t-p}+\beta x_{t}+\mu_{t}$ 
Where $\mathrm{y}_{\mathrm{t}}$ denotes k-vector of integrated of order one, $\mathrm{A}$ is $\mathrm{n} \mathrm{x} \mathrm{n}$ coefficient matrix, $\mathrm{x}_{\mathrm{t}}$ is a vector of deterministic variable, $\mu_{t}$ is $n \times 1$ vector of residuals. Remodeling VAR model takes the following form;

$\Delta \mathrm{y}_{\mathrm{t}}=\prod_{\mathrm{t}-1}+\sum_{\mathrm{i}=1}^{\mathrm{p}-1} \Gamma_{\mathrm{i}} \Delta \mathrm{y}_{\mathrm{t}-\mathrm{i}}+\beta \mathrm{x}_{\mathrm{t}}+\mu_{\mathrm{t}}$

Where, $\Pi=\sum_{i=1}^{p} A_{i}-I, \Gamma=-\sum_{j=t+1}^{p} A_{j}$

$\Delta y_{t}$ is $\mathrm{n} \times 1$ vector of variables with the changes in prices at period $\mathrm{t}$, the rank of $\Pi$ determines cointegrating vectors ( $\mathrm{n} \times \mathrm{n}$ long-run matrix) and $\Gamma$ determines short-run dynamics ( $\mathrm{n} \times \mathrm{n}$ coefficient matrix). When the cointegrating vectors are significant then $\Pi$ can decompose as $\alpha \beta^{\prime}$, where $\alpha$ and $\beta$ are n $x$ r column matrices. In the process of equilibrium relations, the expression $\beta^{\prime} \mathrm{y}_{\mathrm{t}-1}$ describes the cointegrating relations of I(1) order variables and $\alpha$ symbolizes the speed of adjustment to bring back equilibrium relations with respect to previous period $\beta^{\prime} \mathrm{y}_{\mathrm{t}-1}$. In order to identify the number of cointegrating vectors, Johansen and Juselius (1990) suggested the Trace statistics and Maximum Eigenvalue Test statistics. Both test equations are as follows:

$\lambda_{\text {trace }}(\mathrm{r})=-\mathrm{T} \sum_{\mathrm{i}=\mathrm{r}+1}^{\mathrm{k}} \ln \left(1-\lambda_{\mathrm{j}}\right)$

$\lambda_{\max }(\mathrm{r}, \mathrm{r}+1)=-\mathrm{T} \ln \left(1-\lambda_{\mathrm{r}+1}\right)$

Where $\mathrm{T}$ is the length of usable observations, $\mathrm{r}$ is the cointegrating vectors. Under $\lambda_{\text {trace }}$ statistics the null hypothesis is tested as $r=r^{*}<\mathrm{k}$ against the alternative hypothesis $r=k$. Similarly, the null hypothesis testing procedure under $\lambda_{\max }$ is $r^{*}<k$ against the alternative hypothesis $r=r+1$.

\subsection{Causality/Block Exogeneity Wald test based on VECM}

According to Engle and Granger (1987), if there is cointegration between a set of variables than in the chain of error correction there are possibilities of finding shortrun dynamics (the direction of causality). For instance in our case, assume that $X_{t}$ is (stock index prices) and $Y_{t}$ is (group of macroeconomic variables for each country), the error correction term for these two different series are as follows:

$$
\begin{aligned}
& \Delta \mathrm{X}_{\mathrm{t}}=\beta_{0}+\sum_{\mathrm{i}=1}^{\mathrm{n}} \beta_{1} \Delta \mathrm{X}_{\mathrm{t}-1}+\sum_{\mathrm{i}=1}^{\mathrm{m}} \beta_{2} \Delta \mathrm{Y}_{\mathrm{t}-1}+\beta_{3} \mathrm{ECT}_{\mathrm{t}-1}+\varepsilon_{1 \mathrm{t}} \\
& \Delta \mathrm{Y}_{\mathrm{t}}=\delta_{0}+\sum_{\mathrm{i}=1}^{\mathrm{n}} \delta_{1} \Delta \mathrm{Y}_{\mathrm{t}-1}+\sum_{\mathrm{i}=1}^{\mathrm{m}} \delta_{2} \Delta \mathrm{X}_{\mathrm{t}-1}+\delta_{3} \mathrm{ECT}_{\mathrm{t}-1}+\varepsilon_{2 \mathrm{t}}
\end{aligned}
$$

$\mathrm{B}$ and $\delta$ are short-run parameters which will be tested using the Wald $\chi^{2}$ test in the VECM model, ECT is Error correction term of the cointegrating equation and $\varepsilon$ is a disturbance term. 


\section{Empirical Results}

The result of the Augmented Dickey-Fuller test (ADF) statistics for determining stationarity and order of integration for data series exhibited in Table 1. ADF test statistics at level and at first differenced series reported a mixed result of stationarity property. The test shows that some data series are $\mathrm{I}(0)$ at the level and other series shows I(1) only when it is differenced appropriately across nine Asian emerging markets. According to Hansen and Juselius (2002), the cointegration test can be used only when the cointegration system consists of at least two variables of integrated order one i.e. I(1). Therefore, the ADF test satisfies this pre-condition for using a cointegration test to examine the long-run association between stock markets and macroeconomic variables.

Table 1. Stationarity and Order of Integration

\begin{tabular}{|c|c|c|c|c|c|c|c|c|c|}
\hline $\begin{array}{l}\text { Data } \\
\text { Series }\end{array}$ & China & India & Indonesia & Korea & Malaysia & Pakistan & Philippines & Taiwan & Thailand \\
\hline SP & $\mathrm{I}(0)$ & $\mathrm{I}(1)$ & $\mathrm{I}(1)$ & $\mathrm{I}(1)$ & I (1) & I (1) & $\mathrm{I}(1)$ & $\mathrm{I}(0)$ & $\mathrm{I}(0)$ \\
\hline CPI & $\mathrm{I}(0)$ & I (1) & $\mathrm{I}(1)$ & $\mathrm{I}(1)$ & $\mathrm{I}(0)$ & I (1) & $\mathrm{I}(1)$ & $\mathrm{I}(0)$ & I (1) \\
\hline Export & I (1) & I (1) & I (0) & I (1) & I (0) & I (1) & I $(0)$ & I (1) & I (1) \\
\hline Forex & I (1) & I (1) & I (1) & I (1) & I (1) & I (1) & I (1) & I $(0)$ & I (1) \\
\hline Import & I (1) & I (1) & I (0) & I (1) & I (0) & I (0) & I (1) & I (1) & $\mathrm{I}(0)$ \\
\hline IP & I $(0)$ & I (1) & I (1) & I (1) & I (1) & I (0) & I (1) & $\mathrm{I}(0)$ & I (1) \\
\hline MS & I (1) & I (1) & I (1) & I (1) & I (1) & I (1) & I (1) & I (1) & I (1) \\
\hline IR & I (1) & I (1) & I $(0)$ & $\mathrm{I}(0)$ & I (1) & I (1) & I (1) & I (1) & I (1) \\
\hline
\end{tabular}

Notes: $I(0)$ and $I(1)$ is the order of integration zero (level) and one (first difference) determined from ADF test statistics.

Source: Authors' Computations.

In the second stage, we established a long-run relationship between stock prices and macroeconomic variables using the Johansen Cointegration Rank test (Table 2). The test confirms the long-run equilibrium relationship between nine Asian emerging stock markets and macroeconomic variables. For South Korea, Malaysia, Pakistan and the Philippines we noted three cointegrating equations (null hypothesis of $r=0$ to $\mathrm{r} \leq 2$ rejected at $5 \%$ significant level). Whereas for China, India, Taiwan and Thailand we found four cointegrating equations (null hypothesis of $r=0$ to $r \leq 3$ rejected at 5\% significant level). The test also rejected the null hypothesis of up to $r$ $\leq 4$ indicating five cointegrating vectors are significant at a $5 \%$ level for Indonesia. This implies that the stock prices of nine Asian emerging markets are driven by macro variables in the long-run.

Table 2. Cointegration Rank Test $\left(\lambda_{\text {trace }}\right)$

\begin{tabular}{|l|l|l|l|l|l|l|l|l|c|}
\hline $\mathbf{H}_{\mathbf{0}}$ & China & India & Indonesia & Korea & Malaysia & Pakistan & Philippines & Taiwan & Thailand \\
\hline $\mathbf{r}=\mathbf{0}$ & $255.19^{* *}$ & $249.43^{* *}$ & $252.02^{* *}$ & $220.97^{* *}$ & $229.50^{* *}$ & $211.98^{* *}$ & $211.20^{* *}$ & $238.01^{* *}$ & $222.85^{* *}$ \\
\hline $\mathbf{r} \leq \mathbf{1}$ & $170.20^{* *}$ & $154.76^{* *}$ & $175.55^{* *}$ & $158.92^{* *}$ & $157.62^{* *}$ & $143.75^{* *}$ & $152.42^{* *}$ & $155.08^{* *}$ & $146.42^{* *}$ \\
\hline $\mathbf{r} \leq \mathbf{2}$ & $119.78^{* *}$ & $110.32^{* *}$ & $122.77^{* *}$ & $109.36^{* *}$ & $106.78^{* *}$ & $102.41^{* *}$ & $103.34^{* *}$ & $110.87^{* *}$ & $105.98^{* *}$ \\
\hline $\mathbf{r} \leq \mathbf{3}$ & $80.35^{* *}$ & $75.64^{* *}$ & $86.04^{* *}$ & 66.99 & 67.77 & 64.88 & 67.08 & $73.30^{* *}$ & $71.34^{* *}$ \\
\hline $\mathbf{r} \leq \mathbf{4}$ & 45.90 & 46.76 & $55.10^{* *}$ & 47.86 & 35.54 & 41.50 & 31.80 & 44.64 & 41.87 \\
\hline $\mathbf{r} \leq \mathbf{5}$ & 21.90 & 24.61 & 28.68 & 29.80 & 17.60 & 24.08 & 14.37 & 21.78 & 22.86 \\
\hline $\mathbf{r} \leq \mathbf{6}$ & 8.27 & 8.01 & 11.38 & 15.50 & 6.86 & 8.46 & 6.10 & 7.60 & 8.96 \\
\hline
\end{tabular}


Relationship between Asian Emerging Stock Markets and Economic Fundamentals: A Cointegration and Block Exogeneity Wald Approach

\begin{tabular}{|l|l|l|l|l|l|l|l|l|l|}
\hline $\mathbf{r} \leq 7$ & 0.72 & 0.10 & 1.64 & 3.84 & 0.30 & 1.98 & 1.10 & 0.03 & 0.62 \\
\hline
\end{tabular}

Notes: $r$ denotes the number of cointegrating vectors. **Significant at $5 \%$ level. Optimal lag length is determined using AIC (China $=3$, India $=3$, Indonesia $=4$, South Korea $=3$, Malaysia $=2$, Pakistan $=7$, Philippines $=2$, Taiwan $=3$ and Thailand $=2)$. Testing Null Hypothesis $\left(H_{0}\right): \rho=0$ (There is no cointegration)

Source: Authors' Computations.

Table 3 illustrates the normalized cointegrating coefficient which signifies the positive or negative relationship between stock prices and macro variables in the long-run. The notable findings suggested that the inflation (CPI) of seven Asian emerging economies (China, India, Indonesia, Korea, Philippines, Taiwan and Thailand) is positively impacting its stock prices. This implies that stock prices can often acts as a better hedge against inflation. The findings of India are consistent with the result of Giri and Joshi (2017). However, the inflation (CPI) of Malaysia and Pakistan has a negative effect on its stock prices. For the country such as China exchange rate and stock prices exhibits a negative relationship whereas other countries exchange rate are positively associated to stock prices. As per theoretical assumptions, the exchange rate is either positively or negatively related to stock prices. Depreciation in currency value sounds effective for import oriented countries (as input prices decrease and thereby encourages firm's earnings) and on the flip side currency appreciation raises the growth of export-oriented countries (as output prices increase in the foreign market and thereby push up firm's profitability). It is argued that finally the economic major forces determine the net effect. The coefficient of export and import together has a contrary impact on the stock prices of all Asian emerging countries except Taiwan and Thailand which has shown a positive impact of export and import on its stock prices.

Table 3. Normalized Cointegrating Coefficient

\begin{tabular}{|c|c|c|c|c|c|c|c|c|}
\hline Markets & SP & CPI & Export & Forex & Import & IP & MS & IR \\
\hline China & 1.0000 & $\begin{array}{c}317.9889 \\
(132.2410)\end{array}$ & $\begin{array}{l}-1.0254 \\
(0.1565)\end{array}$ & $\begin{array}{l}-528.7397 \\
(571.389) \\
\end{array}$ & $\begin{array}{c}0.2468 \\
(0.1778) \\
\end{array}$ & $\begin{array}{c}231.5194 \\
(51.7059)\end{array}$ & $\begin{array}{l}0.0047 \\
(0.0216)\end{array}$ & $\begin{array}{l}822.6990 \\
(429.577)\end{array}$ \\
\hline India & 1.0000 & $\begin{array}{c}2.5106 \\
(2.0718)\end{array}$ & $\begin{array}{l}-0.1146 \\
(0.1122)\end{array}$ & $\begin{array}{c}2.3208 \\
(3.3128)\end{array}$ & $\begin{array}{l}-0.0592 \\
(0.0549)\end{array}$ & $\begin{array}{l}-4.5037 \\
(1.5674)\end{array}$ & $\begin{array}{l}0.0002 \\
(0.0015)\end{array}$ & $\begin{array}{l}-1.8338 \\
(4.8402)\end{array}$ \\
\hline Indonesia & 1.0000 & $\begin{array}{c}0.0040 \\
(0.0019) \\
\end{array}$ & & $\begin{array}{c}3.21 \mathrm{E}-06 \\
(1.4 \mathrm{E}-05) \\
\end{array}$ & & $\begin{array}{l}-0.0069 \\
(0.0046) \\
\end{array}$ & & $\begin{array}{c}0.0044 \\
(0.0066) \\
\end{array}$ \\
\hline Korea & 1.0000 & $\begin{array}{c}1.0263 \\
(0.1797)\end{array}$ & $\begin{array}{c}4.98 \mathrm{E}-07 \\
(1.3 \mathrm{E}-07)\end{array}$ & $\begin{array}{c}0.0023 \\
(0.0026)\end{array}$ & $\begin{array}{l}-4.46 \mathrm{E}-07 \\
(1.1 \mathrm{E}-07)\end{array}$ & $\begin{array}{l}-0.5084 \\
(0.0850)\end{array}$ & $\begin{array}{l}-3.29 \mathrm{E}-06 \\
(9.6 \mathrm{E}-07)\end{array}$ & $\begin{array}{c}1.5076 \\
(0.3982)\end{array}$ \\
\hline Malaysia & 1.0000 & $\begin{array}{r}-16.3080 \\
(4.4344)\end{array}$ & $\begin{array}{c}0.0291 \\
(0.0032)\end{array}$ & $\begin{array}{c}238.8065 \\
(15.4210)\end{array}$ & $\begin{array}{l}-0.0308 \\
(0.0035)\end{array}$ & $\begin{array}{l}-4.1059 \\
(1.4724)\end{array}$ & $\begin{array}{l}0.0004 \\
(0.0001)\end{array}$ & $\begin{array}{c}12.7063 \\
(16.2848)\end{array}$ \\
\hline Pakistan & 1.0000 & $\begin{array}{r}-172.8028 \\
(28.6862) \\
\end{array}$ & $\begin{array}{c}0.0865 \\
(0.0117) \\
\end{array}$ & $\begin{array}{c}95.8132 \\
(27.6696) \\
\end{array}$ & $\begin{array}{l}-0.0244 \\
(0.0052) \\
\end{array}$ & $\begin{array}{r}-228.3866 \\
(35.6702) \\
\end{array}$ & $\begin{array}{l}0.3054 \\
(0.0441) \\
\end{array}$ & $\begin{array}{l}171.2592 \\
(35.0259) \\
\end{array}$ \\
\hline Philippines & 1.0000 & $\begin{array}{c}2.0510 \\
(6.0623)\end{array}$ & $\begin{array}{c}2.67 \mathrm{E}-06 \\
(1.3 \mathrm{E}-06)\end{array}$ & $\begin{array}{c}16.7511 \\
(7.4486)\end{array}$ & $\begin{array}{l}-2.92 \mathrm{E}-06 \\
(9.0 \mathrm{E}-07)\end{array}$ & $\begin{array}{c}3.2413 \\
(2.3636)\end{array}$ & $\begin{array}{l}2.09 \mathrm{E}-05 \\
(4.3 \mathrm{E}-05)\end{array}$ & $\begin{array}{l}-25.4785 \\
(18.0968)\end{array}$ \\
\hline Taiwan & 1.0000 & $\begin{array}{c}8.0871 \\
(5.6001) \\
\end{array}$ & $\begin{array}{l}-0.0024 \\
(0.0003)\end{array}$ & $\begin{array}{c}14.6863 \\
(6.0250)\end{array}$ & $\begin{array}{c}0.0017 \\
(0.0003) \\
\end{array}$ & $\begin{array}{c}4.1324 \\
(1.6211)\end{array}$ & $\begin{array}{l}-4.11 \mathrm{E}-06 \\
(5.4 \mathrm{E}-06)\end{array}$ & $\begin{array}{r}-19.1190 \\
(5.9722) \\
\end{array}$ \\
\hline Thailand & 1.0000 & $\begin{array}{l}-0.1857 \\
(0.6090)\end{array}$ & $\begin{array}{c}0.0003 \\
(4.1 \mathrm{E}-05)\end{array}$ & $\begin{array}{c}2.5964 \\
(0.5702)\end{array}$ & $\begin{array}{l}2.93 \mathrm{E}-05 \\
(3.0 \mathrm{E}-05)\end{array}$ & $\begin{array}{l}-0.6157 \\
(0.2150) \\
\end{array}$ & $\begin{array}{l}-0.0080 \\
(0.0010)\end{array}$ & $\begin{array}{l}-4.0163 \\
(1.1749) \\
\end{array}$ \\
\hline
\end{tabular}

Notes: standard error in parentheses. SP, CPI, FOREX, IP, MS and IR represent Stock Prices, Consumer Price Index, Foreign Exchange Rate, Index of Industrial Production, Money Supply and Interest Rate.

Source: Authors' Computations. 
The association of industrial production (IP) and money supply (MS) with that of stock prices are expected to be positive since stock prices reflect the progress of the economy and the level of economic conditions. From our findings, this argument supports only for China and the Philippines and it is contrary in the case of Korea and Thailand. For the country such as India, Indonesia, Malaysia and Pakistan, Industrial production effect on stock prices is negative whereas money supply leads the stock prices positively in the long-run. The Taiwan industrial production impact on the other hand is positive on its stock prices and money supply brings the negative movement in the stock prices. As per the theoretical background, the association between the stock prices and interest rate expected to be negative.

Firstly changes (increase) in interest rate affect the discount rate and thereby cash flows of the company which further bring down the stock prices. Other explanation is that rise up in interest rate motivates investors towards other alternative assets. So here investors will start selling off their shares with an expectation of higher yield from alternative investment which will result in a decline in stock prices. This explanation supports the findings of India, Philippines, Taiwan and Thailand as we noted a negative relationship between its interest rate and stock prices. But we examined the positive effect of interest on the stock prices of China, Indonesia, Korea, Pakistan and Malaysia.

To examine the long-run dynamics (speed of adjustment towards equilibrium longrun relationship) and short-run causality relationship, the VECM model has estimated. Table 4 presents the result of the equilibrium relationship of nine Asian emerging stock market prices with its set of macro variables. From the error correction framework, stock prices as a dependent variable we noted three significant ECT for China; two significant ECT for Taiwan and Thailand and one significant ECT for India, Indonesia and Pakistan. This indicates the correction of disequilibrium in the long-run relationship between stock prices and macro variables. In the event of disequilibrium, about $-20.26 \%$ (CE4) for China; $-0.13 \%$ (CE2) for India; $-0.10 \%$ (CE1) for Indonesia; $-0.08 \%$ (CE1) for Pakistan; $-0.10 \%$ (CE1) for Taiwan and $-0.09 \%$ (CE1) for Thailand is corrected within a day to retain back the long-run equilibrium. However, the error correction terms (ECT) are insignificant in the case of Korea, Malaysia and the Philippines. This means that although there is a significant cointegrating relationship between its stock prices and macro variables but there is a nullifying impact of error correction. The $\mathrm{R}^{2}$ and $\mathrm{DW}$ in Table 4 describe the reliability of the model and the absence of serial autocorrelation problem.

Table 4. Speed of adjustment towards long-run equilibrium (Error Correction Term$\left.E C T_{t-1}\right)$

\begin{tabular}{|l|l|l|l|l|l|l|l|}
\hline $\begin{array}{l}\text { Stock } \\
\text { Markets }\end{array}$ & CE1 & CE2 & CE3 & CE4 & CE5 & $\mathbf{R}^{2}$ & DW \\
\hline China & $-0.0823^{* * *}$ & -3.0356 & $0.0150^{* * *}$ & $-20.2576^{*}$ & & 0.1984 & 2.0150 \\
\hline India & $-0.1253^{* * *}$ & -0.1957 & 0.0130 & -0.1164 & & 0.1915 & 2.0462 \\
\hline Indonesia & $-0.1038^{* *}$ & $8.71 \mathrm{E}-05$ & $2.99 \mathrm{E}-10$ & $-3.79 \mathrm{E} .06$ & $-9.12 \mathrm{E}-11$ & 0.2474 & 2.0025 \\
\hline
\end{tabular}


Relationship between Asian Emerging Stock Markets and Economic Fundamentals: A Cointegration and Block Exogeneity Wald Approach

\begin{tabular}{|l|l|l|l|l|l|l|l|}
\hline Korea & 0.0183 & 0.0004 & $-2.78 \mathrm{E}-09$ & & & 0.1818 & 2.0296 \\
\hline Malaysia & 0.0326 & 0.1394 & -0.0005 & & & 0.0838 & 2.0296 \\
\hline Pakistan & $-0.0750 * *$ & 0.5412 & -0.0002 & & & 0.3763 & 1.9999 \\
\hline Philippines & $7.26 \mathrm{E}-05$ & 0.1282 & $6.15 \mathrm{E}-09$ & & & 0.0692 & 2.0223 \\
\hline Taiwan & $-0.1013 * * *$ & -1.0291 & $0.0001 *$ & -0.2615 & & 0.1634 & 1.9759 \\
\hline Thailand & $-0.0853 * * *$ & 0.0005 & $-1.24 \mathrm{E}-05 * * *$ & 0.0556 & & 0.0880 & 1.9753 \\
\hline
\end{tabular}

Notes: CE is Cointegrating equations obtained from VECM. ***, **, *denotes 1\%, 5\% and $10 \%$ significant level. DW is Durbin Watson for testing serial autocorrelation.

Source: Authors' Computations.

Table 5, Panel A, B and C exhibits the causality/Block Exogeneity Wald test which signifies the short-run dynamic or the direction of causality between stock prices and macroeconomic variables. With this test we observed the following notable findings:

$>$ In the short-run stock prices of China granger causes to the import, money supply and interest rate but contrary relationships found insignificant. The bidirectional (SP $\leftrightarrow$ Export) causality noted. However, no significant relationship observed between stock prices with that of inflation, exchange rate and industrial production.

$>$ With the exception of feedback relationship (SP $\leftrightarrow$ IP), there is no short-run causality between Indian stock prices and other macro variables such as inflation, export, import, exchange rate, money supply and interest rate.

$>$ In the case of Indonesia, export granger causes to stock prices. The result also shows causality flows from stock prices to exchange rate and money supply. The feedback relationship also exists between inflation and stock prices but other variables such as import, industrial production and interest rate are not associated with stock prices in the short-run.

$>$ There is one-way causality flows from $(\mathrm{CPI} \rightarrow \mathrm{SP}$, Forex $\rightarrow \mathrm{SP}, \mathrm{IP} \rightarrow \mathrm{SP}$ and MS $\rightarrow$ SP). However, other variables are insignificant towards the Korean stock price movement in the short-run.

$>$ With the exception of bidirectional short-run linkages between money supply and stock prices, other variable shows an insignificant relationship with the Malaysian stock market.

$>$ Two pairs of bidirectional (Import $\leftrightarrow$ SP, MS $\leftrightarrow$ SP) and two pairs of unidirectional ( $\mathrm{SP} \rightarrow$ Export and $\mathrm{SP} \rightarrow \mathrm{IP}$ ) relationships observed in the case of the Pakistan stock market.

$>$ In the case of Philippines, causality flows only from stock prices to industrial production and all other macro variables do not relate to the stock market in the short-run.

$>$ There is unidirectional causality moves from Taiwan stock prices to its export, industrial production and interest rate.

$>$ Stock prices of Thailand granger causes to inflation and industrial production. There is also a feedback relationship documented between export and stock prices. 
Table 5. Panel A. Causality/Block Exogeneity Wald test based on VECM

\begin{tabular}{|c|c|c|c|c|c|c|}
\hline \multirow{2}{*}{$\begin{array}{l}\text { Direction of } \\
\text { Causality }\end{array}$} & \multicolumn{2}{|l|}{ China } & \multicolumn{2}{|l|}{ India } & \multicolumn{2}{|l|}{ Indonesia } \\
\hline & $\chi^{2}$ & Results & $\chi^{2}$ & Results & $\chi^{2}$ & Results \\
\hline $\begin{array}{l}\mathrm{CPI} \rightarrow \mathrm{SP} \\
\mathrm{SP} \rightarrow \mathrm{CPI}\end{array}$ & $\begin{array}{l}4.37 \\
5.32\end{array}$ & None & $\begin{array}{l}3.96 \\
3.62\end{array}$ & None & $\begin{array}{c}12.87^{* *} \\
8.16^{*}\end{array}$ & Bidirectional \\
\hline $\begin{array}{l}\text { EXPORT } \rightarrow \\
\text { SP } \\
\text { SP } \\
\rightarrow \text { EXPORT }\end{array}$ & $\begin{array}{l}6.51^{*} \\
7.05^{*}\end{array}$ & Bidirectional & $\begin{array}{l}3.07 \\
4.97\end{array}$ & None & $\begin{array}{c}13.82^{* * * *} \\
1.78\end{array}$ & Unidirectional \\
\hline $\begin{array}{l}\text { FOREX } \rightarrow \text { SP } \\
\text { SP } \rightarrow \text { FOREX }\end{array}$ & $\begin{array}{l}5.95 \\
3.37 \\
\end{array}$ & None & $\begin{array}{l}3.64 \\
5.66 \\
\end{array}$ & None & $\begin{array}{c}2.75 \\
15.61 * * *\end{array}$ & Unidirectional \\
\hline $\begin{array}{l}\text { IMPORT } \rightarrow \text { SP } \\
\text { SP } \rightarrow \text { IMPORT }\end{array}$ & $\begin{array}{l}2.53 \\
6.74 * \\
\end{array}$ & Unidirectional & $\begin{array}{l}4.89 \\
1.62 \\
\end{array}$ & None & $\begin{array}{l}7.16 \\
4.10 \\
\end{array}$ & None \\
\hline $\begin{array}{l}\mathrm{IP} \rightarrow \mathrm{SP} \\
\mathrm{SP} \rightarrow \mathrm{IP}\end{array}$ & $\begin{array}{l}1.14 \\
2.87 \\
\end{array}$ & None & $\begin{array}{l}7.72 * \\
8.21 * *\end{array}$ & Bidirectional & $\begin{array}{l}2.25 \\
4.02 \\
\end{array}$ & None \\
\hline $\begin{array}{l}\mathrm{MS} \rightarrow \mathrm{SP} \\
\mathrm{SP} \rightarrow \mathrm{MS}\end{array}$ & $\begin{array}{l}2.35 \\
8.31 * * \\
\end{array}$ & Unidirectional & $\begin{array}{l}1.89 \\
4.53 \\
\end{array}$ & None & $\begin{array}{c}7.24 \\
12.28 * * \\
\end{array}$ & Unidirectional \\
\hline $\begin{array}{l}\mathrm{IR} \rightarrow \mathrm{SP} \\
\mathrm{SP} \rightarrow \mathrm{IR}\end{array}$ & $\begin{array}{l}1.08 \\
7.77 * \\
\end{array}$ & Unidirectional & $\begin{array}{l}2.65 \\
2.80 \\
\end{array}$ & None & $\begin{array}{l}1.53 \\
4.23 \\
\end{array}$ & None \\
\hline
\end{tabular}

Notes: ***, **, * denotes 1\%, 5\% and 10\% significant level. SP, CPI, FOREX, IP, MS and IR represent Stock Prices, Consumer Price Index, Foreign Exchange Rate, Index of Industrial Production, Money Supply and Interest Rate. Hypothesis testing $\left(\mathrm{H}_{01}\right)=$ Macroeconomic variables do not granger causes to stock prices. $\left(\mathrm{H}_{02}\right)=$ Stock prices do not granger causes to macroeconomic variables. Optimal lag length is determined using AIC $($ China $=3$, India $=3$, Indonesia $=4$, South Korea $=3$, Malaysia $=2$, Pakistan $=7$, Philippines $=2$, Taiwan $=3$ and Thailand $=2$ ).

Source: Authors' Computations.

Table 5. Panel B. Causality/Block Exogeneity Wald test based on VECM

\begin{tabular}{|c|c|c|c|c|c|c|}
\hline \multirow[b]{2}{*}{$\begin{array}{l}\text { Direction of } \\
\text { Causality }\end{array}$} & \multicolumn{2}{|l|}{ Korea } & \multicolumn{2}{|c|}{ Malaysia } & \multicolumn{2}{|l|}{ Pakistan } \\
\hline & $\chi^{2}$ & Results & $\chi^{2}$ & Results & $\chi^{2}$ & Results \\
\hline $\begin{array}{l}\mathrm{CPI} \rightarrow \mathrm{SP} \\
\mathrm{SP} \rightarrow \mathrm{CPI}\end{array}$ & $\begin{array}{l}10.45^{* *} \\
6.15 \\
\end{array}$ & Unidirectional & $\begin{array}{l}2.57 \\
1.87 \\
\end{array}$ & None & $\begin{array}{l}9.90 \\
6.14 \\
\end{array}$ & None \\
\hline $\begin{array}{l}\text { EXPORT } \rightarrow \text { SP } \\
\text { SP } \rightarrow \text { EXPORT }\end{array}$ & $\begin{array}{l}2.63 \\
0.97 \\
\end{array}$ & None & $\begin{array}{l}1.73 \\
2.88 \\
\end{array}$ & None & $\begin{array}{c}6.25 \\
25.34 * * * \\
\end{array}$ & Unidirectional \\
\hline $\begin{array}{l}\text { FOREX } \rightarrow \text { SP } \\
\text { SP } \rightarrow \text { FOREX }\end{array}$ & $\begin{array}{l}7.08^{*} \\
6.19 \\
\end{array}$ & Unidirectional & $\begin{array}{l}0.58 \\
2.92\end{array}$ & None & $\begin{array}{l}8.12 \\
4.20 \\
\end{array}$ & None \\
\hline $\begin{array}{l}\text { IMPORT } \rightarrow \text { SP } \\
\text { SP } \rightarrow \text { IMPORT }\end{array}$ & $\begin{array}{l}1.82 \\
0.30 \\
\end{array}$ & None & $\begin{array}{l}0.56 \\
3.52 \\
\end{array}$ & None & $\begin{array}{l}20.07 * * * \\
27.44 * * * \\
\end{array}$ & Bidirectional \\
\hline $\begin{array}{l}\mathrm{IP} \rightarrow \mathrm{SP} \\
\mathrm{SP} \rightarrow \mathrm{IP}\end{array}$ & $\begin{array}{l}6.66^{*} \\
1.83 \\
\end{array}$ & Unidirectional & $\begin{array}{l}0.88 \\
1.66\end{array}$ & None & $\begin{array}{c}7.97 \\
12.68 *\end{array}$ & Unidirectional \\
\hline $\begin{array}{l}\mathrm{MS} \rightarrow \mathrm{SP} \\
\mathrm{SP} \rightarrow \mathrm{MS}\end{array}$ & $\begin{array}{l}6.69^{*} \\
4.28 \\
\end{array}$ & Unidirectional & $\begin{array}{l}5.13^{*} \\
4.98^{*}\end{array}$ & Bidirectional & $\begin{array}{l}15.74 * * \\
29.30 * * *\end{array}$ & Bidirectional \\
\hline $\begin{array}{l}\mathrm{IR} \rightarrow \mathrm{SP} \\
\mathrm{SP} \rightarrow \mathrm{IR}\end{array}$ & $\begin{array}{l}4.16 \\
3.32 \\
\end{array}$ & None & $\begin{array}{l}1.01 \\
3.23 \\
\end{array}$ & None & $\begin{array}{l}8.90 \\
5.09 \\
\end{array}$ & None \\
\hline
\end{tabular}

Notes: ***, **, * denotes 1\%, 5\% and 10\% significant level. SP, CPI, FOREX, IP, MS and IR represent Stock Prices, Consumer Price Index, Foreign Exchange Rate, Index of Industrial Production, Money Supply and Interest Rate. Hypothesis testing $\left(\mathrm{H}_{01}\right)=$ Macroeconomic variables do not granger causes to stock prices. $\left(H_{02}\right)=$ Stock prices do not granger causes to macroeconomic variables. Optimal lag length is determined using AIC $($ China $=3$, India $=3$, Indonesia $=4$, South Korea $=3$, Malaysia $=2$, Pakistan $=7$, Philippines $=2$, Taiwan $=3$ and Thailand $=2$ ).

Source: Authors' Computations. 
Relationship between Asian Emerging Stock Markets and Economic Fundamentals: A Cointegration and Block Exogeneity Wald Approach

Table 5. Panel C. Causality/Block Exogeneity Wald test based on VECM

\begin{tabular}{|c|c|c|c|c|c|c|}
\hline \multirow[b]{2}{*}{$\begin{array}{l}\text { Direction of } \\
\text { Causality }\end{array}$} & \multicolumn{2}{|c|}{ Philippines } & \multicolumn{2}{|l|}{ Taiwan } & \multicolumn{2}{|l|}{ Thailand } \\
\hline & $\chi^{2}$ & Results & $\chi^{2}$ & Results & $\chi^{2}$ & Results \\
\hline $\begin{array}{l}\mathrm{CPI} \rightarrow \mathrm{SP} \\
\mathrm{SP} \rightarrow \mathrm{CPI}\end{array}$ & $\begin{array}{l}1.18 \\
3.33\end{array}$ & None & $\begin{array}{l}4.27 \\
5.53\end{array}$ & None & $\begin{array}{c}1.08 \\
16.64 * * *\end{array}$ & Unidirectional \\
\hline $\begin{array}{l}\text { EXPORT } \rightarrow \text { SP } \\
S P \rightarrow \text { EXPORT }\end{array}$ & $\begin{array}{l}0.30 \\
0.19\end{array}$ & None & $\begin{array}{l}5.77 \\
11.77 * * * \\
\end{array}$ & Unidirectional & $\begin{array}{r}9.32 * * * \\
10.10^{* * * *}\end{array}$ & Bidirectional \\
\hline $\begin{array}{l}\text { FOREX } \rightarrow \text { SP } \\
\text { SP } \rightarrow \text { FOREX }\end{array}$ & $\begin{array}{l}1.86 \\
0.27\end{array}$ & None & $\begin{array}{l}2.71 \\
3.10 \\
\end{array}$ & None & $\begin{array}{l}0.55 \\
4.51 \\
\end{array}$ & None \\
\hline $\begin{array}{l}\text { IMPORT } \rightarrow \text { SP } \\
\text { SP } \rightarrow \text { IMPORT }\end{array}$ & $\begin{array}{l}0.56 \\
2.98 \\
\end{array}$ & None & $\begin{array}{l}2.69 \\
4.42 \\
\end{array}$ & None & $\begin{array}{l}1.40 \\
3.53 \\
\end{array}$ & None \\
\hline $\begin{array}{l}\mathrm{IP} \rightarrow \mathrm{SP} \\
\mathrm{SP} \rightarrow \mathrm{IP}\end{array}$ & $\begin{array}{l}2.39 \\
9.76^{* * * *}\end{array}$ & Unidirectional & $\begin{array}{l}5.27 \\
15.72 * * * \\
\end{array}$ & Unidirectional & $\begin{array}{l}1.29 \\
8.30 * *\end{array}$ & Unidirectional \\
\hline $\begin{array}{l}\mathrm{MS} \rightarrow \mathrm{SP} \\
\mathrm{SP} \rightarrow \mathrm{MS}\end{array}$ & $\begin{array}{l}2.31 \\
2.57 \\
\end{array}$ & None & $\begin{array}{l}2.72 \\
1.86 \\
\end{array}$ & None & $\begin{array}{l}1.70 \\
2.75 \\
\end{array}$ & None \\
\hline $\begin{array}{l}\mathrm{IR} \rightarrow \mathrm{SP} \\
\mathrm{SP} \rightarrow \mathrm{IR}\end{array}$ & $\begin{array}{l}0.76 \\
0.02\end{array}$ & None & $\begin{array}{l}2.32 \\
9.58 * *\end{array}$ & Unidirectional & $\begin{array}{l}0.52 \\
2.60 \\
\end{array}$ & None \\
\hline
\end{tabular}

Notes: ***, **, * denotes 1\%, 5\% and 10\% significant level. SP, CPI, FOREX, IP, MS and IR represent Stock Prices, Consumer Price Index, Foreign Exchange Rate, Index of Industrial Production, Money Supply and Interest Rate. Hypothesis testing $\left(\mathrm{H}_{01}\right)=$ Macroeconomic variables do not granger causes to stock prices. $\left(H_{02}\right)=$ Stock prices do not granger causes to macroeconomic variables. Optimal lag length is determined using AIC $($ China $=3$, India $=3$, Indonesia $=4$, South Korea $=3$, Malaysia $=2$, Pakistan $=7$, Philippines $=2$, Taiwan $=3$ and Thailand $=2$ ).

Source: Authors' Computations.

\section{Conclusion}

This research examines whether there is a short-run and long-run association between nine Asian emerging stock markets (China, India, Indonesia, Korea, Malaysia, Philippines, Pakistan, Taiwan and Thailand) and their underlying economic fundamentals (CPI, Export, Import, Forex, IP, MS and IR). We noted a mixed result that the macroeconomic variables of the countries are either positively or negatively linked to stock prices depending upon the country's financial structure.

The result of the Cointegration test shows the stable long-run relationship of stock prices with those variables. The error correction mechanism also stated the speed of adjustment towards the long-run equilibrium relationship between six Asian emerging stock markets (China, India, Pakistan, Thailand, Indonesia and Taiwan) and their macroeconomic variables. However, it should be noted that the short-run causality between stock prices and macro factors are considerably limited across all nine Asian emerging stock markets. Finally, all the Asian stock markets are sensitive and their stock prices are determined by the changes in economic activities.

The results of the study are consistent with Wongbangpo and Sharma (2002), Hosseini et. al. (2011) that there is a short-run and long-run interaction between macroeconomic variables and stock prices. Kwon and Shin (1999) claimed that stock price volatility is fundamentally linked to economic activities while Bilson et. al. (2001) stated that macroeconomic variables are associated with emerging equity 
returns. The insight on the linkages between stock prices and economic fundamentals will provide the opportunity for short-run and long-run investment decisions in the Asian emerging stock markets.

The Portfolio investors across a world are looking out constantly at a number of developed, emerging and frontier stock markets to diversify their portfolio. However, most of them preferring emerging stock markets to diversify their risk and retain higher portfolio returns. Nevertheless, they also need to perceive a higher risk in these markets as compared to developed markets. Therefore, while structuring the asset allocation strategy, they need to keep a close watch towards the pace of development and reforms in economic fundamentals. Similarly, returns variation should not be monitored only at the country macro level but foreign macro news should also be catered. Due to the strong connectedness between the stock market and economic parameters, the sudden decline in the economy will create fear amongst investors and will force them to take off their investment from the markets. In turn, the growth of the economy will retard. Therefore, to maintain stability in the economic growth of the country the policymakers should draft a prudent economic and financial policy.

\section{References:}

Batareddy, M., Gopalaswamy, A.K., Huang, C.H. 2012. The stability of long-run relationships: A study on Asian emerging and developed stock markets (Japan and US). International Journal of Emerging Markets, 7(1), 31-48.

Bilson, C.M., Brailsford, T.J., Hooper, V.J. 2001. Selecting macroeconomic variables as explanatory factors of emerging stock market returns. Pacific-Basin Finance Journal, 9, 401-426.

Brahmasrene, I., Jiranyakul, K. 2007. Cointegration and causality between stock index and macroeconomic variables in an emerging market. Academy of Accounting and Financial Studies Journal, 11(3), 17-30.

Dickey, D.A., Fuller, W.A. 1979. Distribution of the Estimators for Autoregressive Time Series With a Unit Root. Journal of the American Statistical Association, 74(366), 427-431.

Dunis, C.L., Shannon, G. 2005. Emerging Markets of South-East and Central Asia: Do They Still Offer a Diversification Benefit? Journal of Asset Management, 6, 168-190.

Eiling, E., Gerard, B. 2015. Emerging Equity Market Comovements: Trends and Macroeconomic Fundamentals. Review of Finance, 19, 1543-1585.

Engle, R.F., Granger, C.W. 1987. Co-Integration and Error Correction: Representation, Estimation, and Testing. Econometrica, 55(2), 251-276.

Fama, E.F. 1970. Efficient Capital Markets: A Review of Theory and Empirical Work. The Journal of Finance, 25(2), 383-417.

Giri, A.K., Joshi, P. 2017. The impact of macroeconomic indicators on Indian stock prices: An empirical analysis. Studies in Business and Economics, 12(1), 61-78.

Grossman, S.J., Shiller, R.J. 1980. The determinants of the variability of stock market prices. NBER, Working Paper No. 564, 1-9.

Hansen, H., Juselius, K. 2002. CATS in RATS. Cointegration Analysis of Time Series. Evanstone, IL, Estima. 
Hosseini, S.M., Ahmad, Z., Lai, Y.W. 2011. The Role of Macroeconomic Variables on Stock Market Index in China and India. International Journal of Economics and Finance, 3 (6), 233-243.

Ibrahim, M. 2003. Macroeconomic forces and capital market integration: A VAR analysis for Malaysia. Journal of the Asia Pacific Economy, 8(1), 19-40.

Johansen, S., Juselius, K. 1990. Maximum Likelihood Estimation and Inference on Cointegration - With Applications to the Demand for Money. Oxford Bulletin of Economics and Statistics, 52(2), 169-210.

Johnson, R., Soenen, L. 2002. Asian Economic Integration and Stock Market Comovement. The Journal of Financial Research, XXV(1), 141-157.

Kwon, C.S., Shin, T.S. 1999. Cointegration and causality between macroeconomic variables and stock market returns. Global Finance Journal, 10(1), 71-81.

Lee, U. 1997. Stock Market and Macroeconomic Policies: New Evidence from Pacific Basin Countries. Multinational Finance Journal, 1(4), 273-289.

Loong, T.K., Har, W.P. 2017. Global share market integration and diversification: A study of Asian emerging market. Asian Economic and Financial Review, 7(10), 981-991.

Maysami, R.C., Hui, S.H. 2001. An Empirical Investigation of the Dynamic Relations between Macroeconomic Factors and the Stock Markets of Malaysia and Thailand. Journal Pengurusan, 20, 3-26.

Pal, K., Mittal, R. 2011. Impact of macroeconomic indicators on Indian capital markets. The Journal of Risk Finance, 12(2), 84-97.

Pretorius, E. 2002. Economic determinants of emerging stock market interdependence. Emerging Markets Review, 3, 84-105.

Sohail, N., Hussain, Z. 2009. Long-run and short-run relationship between macroeconomic variables and stock prices in Pakistan. Pakistan Economic and Social Review, 47 (2), 183-198.

Surbakti, E.H., Achsani, N.A., Ahmad Maulana, T.N. 2016. The Impact of Macroeconomic Variables on JCI's Stock Return Volatility in Pre and Post Global Economic Crisis. International Journal of Scientific and Research Publications, 6(3), 213-219.

Thalassinos, I.E., Thalassinos, E.P. 2006. Stock Markets' Integration Analysis. European Research Studies Journal, 9(3-4), 3-14.

Thalassinos, I.E., Stamatopoulos, D.T. and Thalassinos, E.P. 2015. The European Sovereign Debt Crisis and the Role of Credit Swaps. Chapter book in The WSPC Handbook of Futures Markets (eds) W. T. Ziemba and A.G. Malliaris, in memory of Late Milton Miller (Nobel 1990) World Scientific Handbook in Financial Economic Series Vol. 5, Chapter 20, pp. 605-639. DOI: 10.1142/9789814566926_0020.

Umer, M. 2016. Macroeconomic Variables Impact on Stock Market Performance in the Short \& Long Run: A Pakistan Perspective. Research Journal of Finance and Accounting, 7(11), 10-22.

Valukonis, M. 2013. China's stock market trends and their determinants analysis using market indices. Economics and Management, 18(4), 651-660.

Wongbangpo, P., Sharma, S.C. 2002. Stock market and macroeconomic fundamental dynamic interactions: ASEAN-5 countries. Journal of Asian Economics, 13, 27-51. 